\title{
Changes in expression of bone morphogenetic proteins (BMPs), their receptors and inhibin co-receptor betaglycan during bovine antral follicle development: inhibin can antagonize the suppressive effect of BMPs on thecal androgen production
}

\author{
Claire Glister, Leanne Satchell and Philip G Knight \\ School of Biological Sciences, Hopkins Building, University of Reading, Whiteknights, Reading RG6 6UB, UK
}

Correspondence should be addressed to P G Knight; Email: p.g.knight@reading.ac.uk

\begin{abstract}
We reported previously that bone morphogenetic proteins (BMPs) potently suppress CYP17 expression and androgen production by bovine theca interna cells (TC) in vitro. In this study, real-time PCR was used to analyse gene expression in TC and granulosa cell (GC) layers from developing bovine antral follicles (1-18 mm). Abundance of mRNA transcripts for four BMPs (BMP2, BMP4, BMP6, and $B M P 7)$ and associated type I (BMPR1A, BMPR1B, ACVR1 and ACVR1B) and type II (BMPR2, ACVR2A and ACVR2B) receptors showed relatively modest, though significant, changes during follicle development. $B M P 2$ was selectively expressed in GC, while $B M P 6, B M P 7$ and betaglycan (TGFBR3) were more abundant in TC. Abundance of betaglycan mRNA (inhibin co-receptor) in TC increased progressively (fivefold; $P<0.001$ ) as follicles grew from 1-2 to 9-10 mm. This suggests a shift in thecal responsiveness to GC-derived inhibin, produced in increasing amounts as follicles achieve dominance. This prompted us to investigate whether inhibin can function as a physiological antagonist of BMP action on bovine TC in vitro, in a manner comparable to that for activin signalling. BMP4, BMP6 and BMP7 abolished LH-induced androstenedione secretion and suppressed CYP17 mRNA $>200$-fold $(P<0.001)$, while co-treatment with inhibin-A reversed the suppressive action of BMP in each case $(P<0.001)$. Results support a physiological role for granulosa-derived inhibin as an antagonist of BMP action on thecal androgen synthesis. A shift in intrafollicular balance between thecal BMP signalling (inhibitory for androgen synthesis) and betaglycan-dependent inhibin signalling (stimulatory for androgen synthesis) accords with the physiological requirement to deliver an adequate supply of aromatase substrate to GC of developing follicles.
\end{abstract}

Reproduction (2010) $\mathbf{1 4 0}$ 699-712

\section{Introduction}

The mechanisms controlling the recruitment, selection, dominance, ovulation and/or regression of follicles in the mammalian ovary have yet to be fully delineated. A multitude of intraovarian factors engage in autocrine/paracrine signalling between theca interna cells (TC), granulosa cells (GC) and oocytes, and contribute to a coordinated programme of follicle cell proliferation and differentiation. Particularly in the later stages of follicle development, intraovarian factors also modulate the sensitivity of follicular cells to gonadotrophins and other extraovarian factors (Mihm et al. 2002, Webb et al. 2003). Among this growing list of locally produced regulatory factors are various members of the transforming growth factor- $\beta$ (TGFB) superfamily, including inhibins, activins and bone morphogenetic proteins (BMPs; reviews: Ying 1988, Knight \& Glister 2001, 2006, Welt et al. 2002, Shimasaki et al. 2004).

Numerous studies have documented the spatiotemporal patterns of mRNA and/or protein expression for inhibin/activin $\alpha / \beta$ subunits (INHA, INHBA and $I N H B B)$ during follicle development in several species (reviews: De Jong 1988, Ying 1988, Knight \& Glister 2001). To a lesser extent, follicular expression patterns of several BMPs have also been reported (Erickson \& Shimasaki 2003, Glister et al. 2004, Shimasaki et al. 2004, Fatehi et al. 2005, Juengel et al. 2006). In addition, functional studies have provided clear evidence that inhibins, activins and BMPs exert local intraovarian roles. For instance, activin and several BMPs can suppress androgen production by cultured TC (Hillier et al. 1991, Dooley et al. 2000, Glister et al. 2005), while inhibin can enhance $\mathrm{LH}$-induced androgen secretion (Hsueh et al. 1987, Hillier et al. 1991, Wrathall \& Knight 1995). Activins and BMPs may promote GC proliferation, upregulate $\mathrm{FSH}$ receptor expression and enhance oestradiol $\left(E_{2}\right)$ production while inhibiting progesterone $\left(\mathrm{P}_{4}\right)$ production (Hasegawa et al. 1988, Xiao et al. 1992, Findlay \& Drummond 1999, Glister et al. 2004, Juengel et al. 2006). 
In common with other TGFB family ligands, BMP signalling involves ligand-induced formation of a heteromeric complex with two types of serine/threonine kinase receptors referred to as type I and type II (Massague \& Chen 2000, Miyazono et al. 2000, Miyazawa et al. 2002). In a combinatorial manner, different BMP ligands bind to one of four different type I receptors such as ACVR1 (ALK2), BMPR1A (ALK3), ACVR1B (ALK4) and BMPR1B (ALK6), before recruiting one of three type II receptors (BMPR2, ACVR2A and ACVR2B) to form an active signalling complex. With regard to type I receptors, evidence suggests that BMP2 and BMP4 preferentially bind BMPR1A and/or BMPR1B, while BMP6 and BMP7 tend to bind ACVR1 and/or BMPR1B (ten Dijke et al. 1994, Ebisawa et al. 1999, Aoki et al. 2001). With regard to type II receptors, BMP6, BMP7 and activin preferentially recruit ACVR2A, while BMP2, BMP4, BMP6, BMP7 and BMP15, but not activin, recruit BMPR2 (Liu et al. 1995, Nohno et al. 1995, Yamashita et al. 1995, Ebisawa et al. 1999, Moore et al. 2003). Signalling complex formation leads to the type II receptor transphosphorylating (activating) the intracellular kinase domain of the type I receptor, which, in turn, phosphorylates BMP-responsive transcription factors SMADs $1 / 5 / 8$. These associate with a common partner SMAD (SMAD4) and translocate to the nucleus to modify target gene expression (Miyazono et al. 2005, 2010).

Inhibins antagonize the biological effects of activins by binding to activin type II receptors thus inhibiting the formation of activin-induced signalling complexes and subsequent activation of activin-responsive SMADs 2/3 (Harrison et al. 2004). For effective presentation of inhibin to type II activin receptors' co-expression of another cell surface molecule, betaglycan (also known as TGFBR3) is essential. Thus, betaglycan functions as an important co-receptor for inhibin as well as TGFB, greatly enhancing the efficacy of both ligands. Betaglycan is abundantly expressed on the surface of many cell types, and a soluble form may also be generated by proteolytic cleavage of the membrane-bound receptor (Cook et al. 2004).

In addition to its classical role as an activin antagonist, inhibin may also function as a competitive antagonist of BMPs through the same betaglycan-dependent mechanism, involving competition between inhibin and BMPs for type II receptor(s) utilized by BMPs (Wiater \& Vale 2003, Farnworth et al. 2006). Thus, betaglycan and inhibin have emerged as potentially important players in the regulation of BMP signalling, although the extent to which this may apply in the ovarian follicle has not been addressed.

Immunocytochemical studies on bovine ovarian cells in primary culture have documented the expression of multiple BMP ligands and BMP-responsive type I and type II receptors (Glister et al. 2004). However, information is lacking on the extent to which cellular expression of different BMP ligands and their receptors varies during bovine follicle development. With the above points in mind, the initial objective of this study was to use real-time PCR for a detailed analysis of ex vivo gene expression profiles for a range of BMPs, inhibin/ activin subunits, their type I and type II signalling receptors and the inhibin co-receptor betaglycan in GC and TC layers isolated from developing bovine antral follicles. The changes we observed in betaglycan expression in TC, together with the aforementioned reports from studies using immortalized testicular, adrenocortical and gonadotroph cell lines (Wiater \& Vale 2003, Farnworth et al. 2006), prompted us to use our bovine TC culture model to test the hypothesis that inhibin antagonizes the suppressive effect of BMPs on follicular androgen production.

\section{Results}

\section{Pre-screening of follicle samples included in the analysis}

Overall, $24 / 118(20 \%)$ of samples (from pooled or individual follicles) prepared for gene expression analysis were rejected and excluded from the study because they did not meet our quality control criterion of $<5 \%$ GC/TC cross-contamination as evidenced by relative expression levels of cell-specific 'marker' transcripts (TC marker: CYP17; GC markers: FSHR and CYP19). Following this screening process, respective $n$ values were 4,5 and 5 for $1-2,3-4$ and 5-6 mm follicle pools and 8, 7, 9 and 9 for individual follicles in the 7-8 mm, 9-10 mm, large $(11-18 \mathrm{~mm})$ oestrogen-active (LEA) and large $(11-18 \mathrm{~mm}$ ) oestrogen-inactive (LEI) categories (see Materials and Methods section for further details).

\section{Follicular fluid steroid concentrations in developing antral follicles}

Figure 1 shows the follicular fluid concentrations $(\mathrm{ng} / \mathrm{ml}$ protein) of $\mathrm{P}_{4}$, androstenedione $\left(\mathrm{A}_{4}\right)$ and $\mathrm{E}_{2}$ in the antral follicle set analysed. A progressive increase $(P<0.001)$ in $E_{2}$ concentration accompanied follicle development to the LEA stage, and this was associated with a concomitant decline in $\mathrm{A}_{4}(P<0.001)$, reflecting increased aromatization by follicular GC. In comparison with LEA follicles, LEI follicles had approximately eightfold lower $E_{2}(P<0.01)$, approximately fourfold higher $\mathrm{P}_{4}(P<0.05)$ and approximately twofold higher $\mathrm{A}_{4}(P>0.05 ; \mathrm{NS})$ concentrations.

\section{mRNA expression profiles for gonadotrophin receptors, key steroidogenic enzymes and INHBA subunit in developing antral follicles}

The observed patterns of mRNA expression for FSHR, LHCGR, CYP19, CYP17 and INHBA in GC and TC of developing antral follicles accorded with expectations (Fig. 2). FSHR mRNA was abundant in GC throughout 


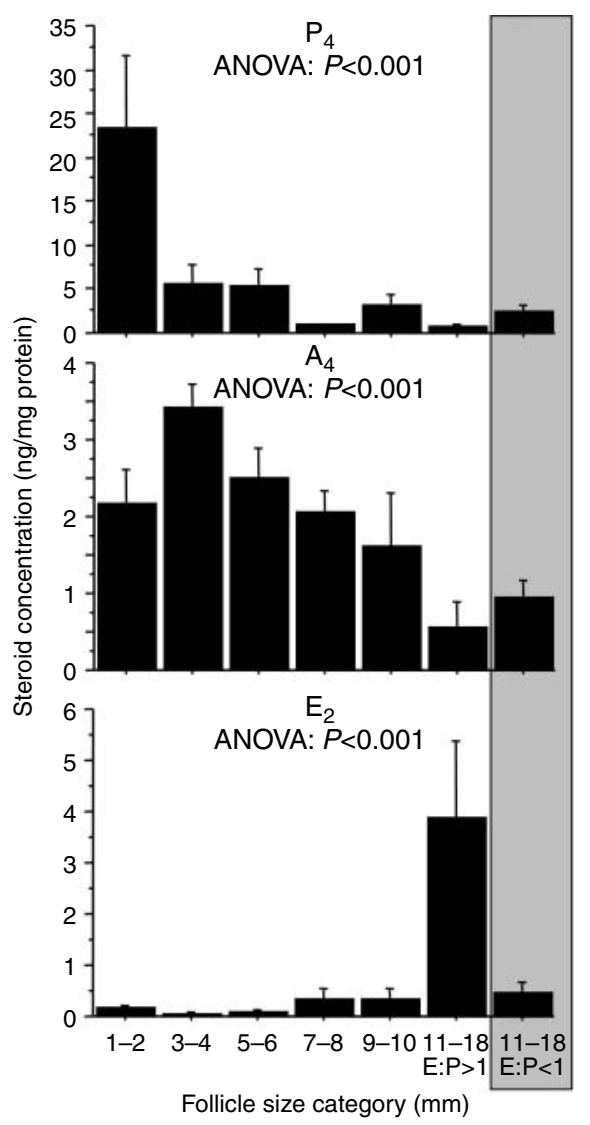

Figure 1 Concentrations (ng/mg protein) of progesterone $\left(\mathrm{P}_{4}\right)$, androstenedione $\left(\mathrm{A}_{4}\right)$ and oestradiol $\left(\mathrm{E}_{2}\right)$ in follicular fluid samples from developing bovine antral follicles. Follicles in the 11-18 $\mathrm{mm}$ size class have been subdivided on the basis of oestrogen to progesterone ratio (E:P ratio) as 'oestrogen-active' ( $\mathrm{E}: \mathrm{P}$ ratio $>1$ ) or 'oestrogen-inactive' (E:P ratio $<1)$. Values are means, and bars indicate S.E.M. $(n=4-9)$. $P$ values from ANOVA are indicated.

antral follicle development, while GC of follicles $>9 \mathrm{~mm}$ also expressed LHCGR. Moreover, LEA follicles had much higher levels of $L H C G R, F S H R$ and INHBA mRNA than LEl follicles $(P<0.001)$. LHCGR expression was abundant in TC at all stages examined, but transcript levels were lowest in LEA follicles. Expression of CYP17 mRNA was specific for TC, being abundant at all stages, while CYP19 and INHBA mRNAs were largely confined to GC of large follicles, being approximately sixfold greater in LEA follicles than in LEI follicles $(P<0.001)$.

\section{Expression profiles for BMP2, BMP4, BMP6 and BMP7 mRNAs in developing antral follicles}

Developmental changes in the relative abundance of mRNA transcripts for $B M P 2, B M P 4, B M P 6$ and $B M P 7$ in antral follicles are shown in Fig. 3. Overall, $B M P 2 \mathrm{mRNA}$ was selectively expressed in GC $(P<0.0001)$, while $B M P 4, B M P 6$ and $B M P 7$ transcripts were more abundant in TC than in GC $(P<0.0001)$. In GC, BMP2 mRNA abundance was much lower in LEA follicles than in other follicle categories $(P<0.05$ compared with 3-4, 5-6 and 7-8 mm follicles; NS compared with 1-2 mm, 9-10 mm and LEI follicles), while in TC, BMP2 mRNA was maximal in LEA follicles $(P<0.05$ compared with 1-2 mm, 2-3 mm, 5-6 mm, 7-8 mm and LEI follicles). In GC, BMP4 mRNA level was highest in large $(11-20 \mathrm{~mm})$ follicles regardless of $\mathrm{E}: \mathrm{P}$ ratio; in $\mathrm{TC}$, BMP4 mRNA level was approximately twofold higher in larger $(7-18 \mathrm{~mm})$ follicles than in 1-6 $\mathrm{mm}$ follicles $(P<0.05)$. The relative abundance of BMP6 mRNA in GC or in TC did not vary across follicle development. Likewise, BMP7 transcript abundance in TC was uniform. However, $B M P 7$ expression in GC was lowest in $7-8 \mathrm{~mm}$ follicles $(P<0.05$ compared with $1-2$ and 11-18 mm follicles).

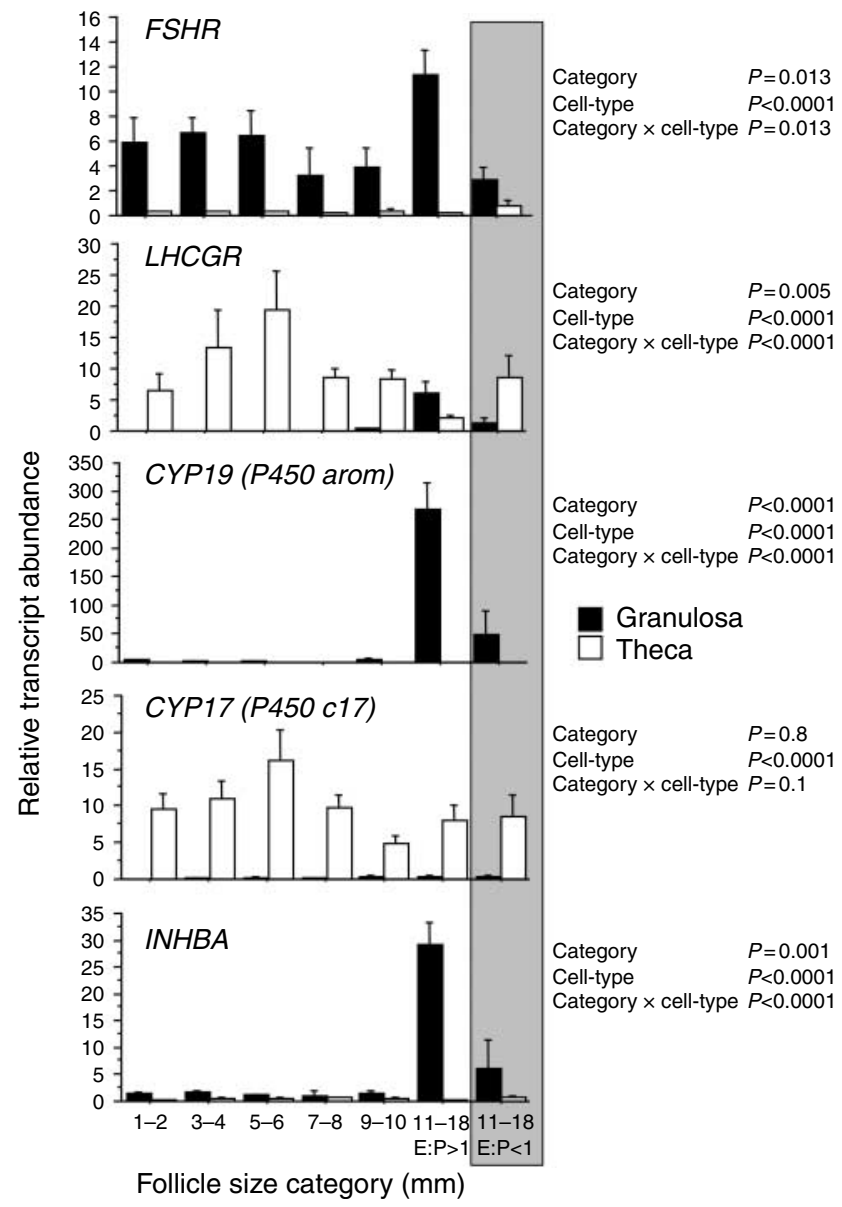

Figure 2 Changes in relative abundance of mRNA transcripts for gonadotrophin receptors (FSHR and $L H C G R$ ), steroidogenic enzymes (CYP17 and CYP19) and inhibin/activin $\beta A$ subunit (INHBA) in thecal and granulosal compartments of developing bovine antral follicles. Follicles in the 11-18 $\mathrm{mm}$ size class have been subdivided on the basis of oestrogen to progesterone ratio (E:P ratio) as 'oestrogen-active' $(\mathrm{E}: \mathrm{P}$ ratio $>1)$ or 'oestrogen-inactive' $(\mathrm{E}: \mathrm{P}$ ratio $<1)$. Values are means, and bars indicate S.E.M. $(n=4-9)$. Results of two-way ANOVA are summarized. 


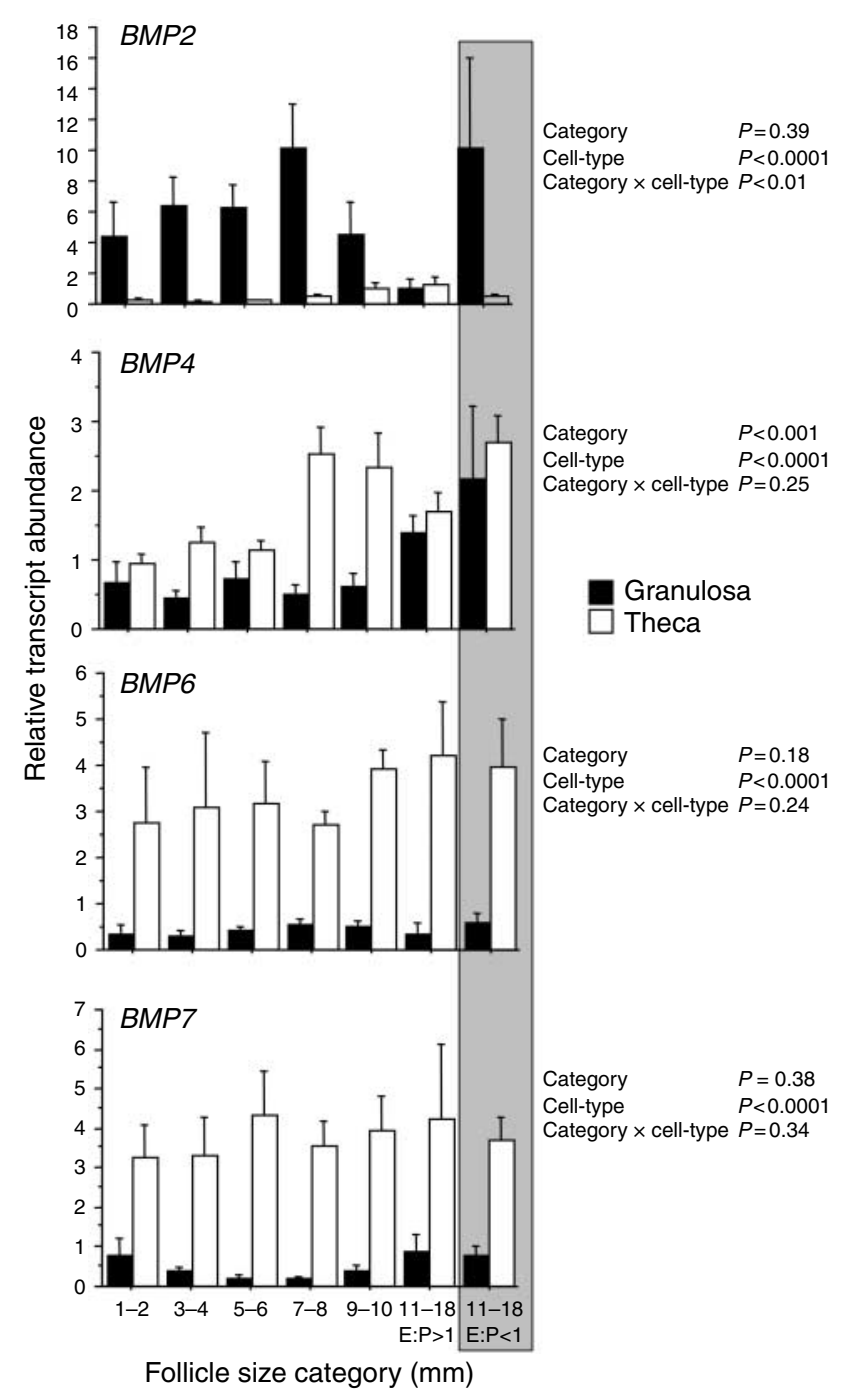

Figure 3 Changes in relative abundance of mRNA transcripts for $B M P 2$, $B M P 4, B M P 6$ and BMP7 in thecal and granulosal compartments of developing bovine antral follicles. Follicles in the $11-18 \mathrm{~mm}$ size class have been subdivided on the basis of oestrogen to progesterone ratio (E:P ratio) as 'oestrogen-active' (E:P ratio $>1$ ) or 'oestrogen-inactive' (E:P ratio $<1)$. Values are mean, and bars indicate S.E.M. $(n=4-9)$. Results of two-way ANOVA are summarized.

\section{Expression profiles for BMP receptor $\mathrm{mRNAs}$ in developing antral follicles}

Overall, the abundance of transcripts for the four type I (BMPR1A, BMPR1B, ACVR1 and ACVR1B) and three type II (BMPR2, $A C V R 2 A$ and $A C V R 2 B)$ signalling receptors examined showed relatively little variation during follicle development (Fig. 4), and all seven receptors were expressed by both cell types at all follicle stages examined. However, with respect to type I receptors, BMPR1A mRNA level in GC was highest in LEA follicles, while BMPR1A mRNA level in TC was lowest in LEA follicles $(P<0.05)$. BMPR1B expression in GC increased with follicle size
( $P<0.05 ; 1-2$ vs 9-10 $\mathrm{mm}$ follicles), whereas expression in TC decreased with follicle size $(P<0.05 ; 1-2$ vs 11-18 mm follicles). ACVR1 expression in GC also increased with follicle size $(P<0.05 ; 1-2$ vs $11-18 \mathrm{~mm}$ follicles), while expression in TC fell in LEA follicles $(P<0.05$ compared with all follicles $<10 \mathrm{~mm})$. There were no significant differences in $A C V R 1 B$ expression among different follicle categories. With respect to type II receptors, BMPR2 mRNA level in GC increased progressively from 1-2 to 11-18 mm follicle categories $(P<0.01)$ but did not differ between LEA and LEI follicles. Conversely, BMPR2 mRNA level in TC fell from 5-6 mm to LEA follicles $(P<0.05)$ and was lower in LEA follicles than in LEI follicles $(P<0.05)$. GC abundance of $A C V R 2 A$ mRNA increased from 1-2 to 9-10 mm follicles (approximately twofold; $P<0.05$ ) before falling again in LEA follicles $(\sim 50 \%$; $P<0.05)$ but not LEI follicles. Expression of $A C V R 2 B$ mRNA did not vary significantly across follicle development for either cell type.

\section{mRNA expression profile for betaglycan (TGFBR3) in developing follicles}

As shown in Fig. 4, betaglycan mRNA was much more abundant in TC than in GC at all follicle stages examined $(P<0.0001)$. In both cell types, betaglycan mRNA level increased progressively (approximately fivefold; $P<0.001)$ as follicles grow from 1-2 to 9-10 mm. Levels in TC then fell $(P<0.05)$ by about $50 \%$ in $11-18 \mathrm{~mm}$ follicles, whereas levels in GC remained high. There was no significant difference in betaglycan transcript abundance between LEA and LEI follicles.

\section{Immunostaining of BMP ligands, receptors and betaglycan in ovary sections}

To reinforce the above mRNA expression data, bovine ovary sections were immunostained with antibodies against each of the BMP ligands and receptors analysed by real-time PCR. Figure 5 shows the distribution of immunoreactive BMP ligands, BMP/activin receptors and betaglycan in the granulosa and theca layers of small antral follicles ( 3-5 mm diameter). BMP2 and BMP4 immunoreactivity appeared more abundant in the GC layer, while BMP6 and BMP7 immunoreactivity was evident in both GC and TC layers. Similarly, immunoreactivity for each of the seven signalling receptors and betaglycan was evident in both GC and TC layers.

\section{Correlations among expression levels of different transcripts in GC of developing follicles}

Figure 6 is a correlation matrix showing the pairwise relationships between follicle diameter, $E_{2}: P_{4}$ ratio and relative abundance of each transcript in GC. 

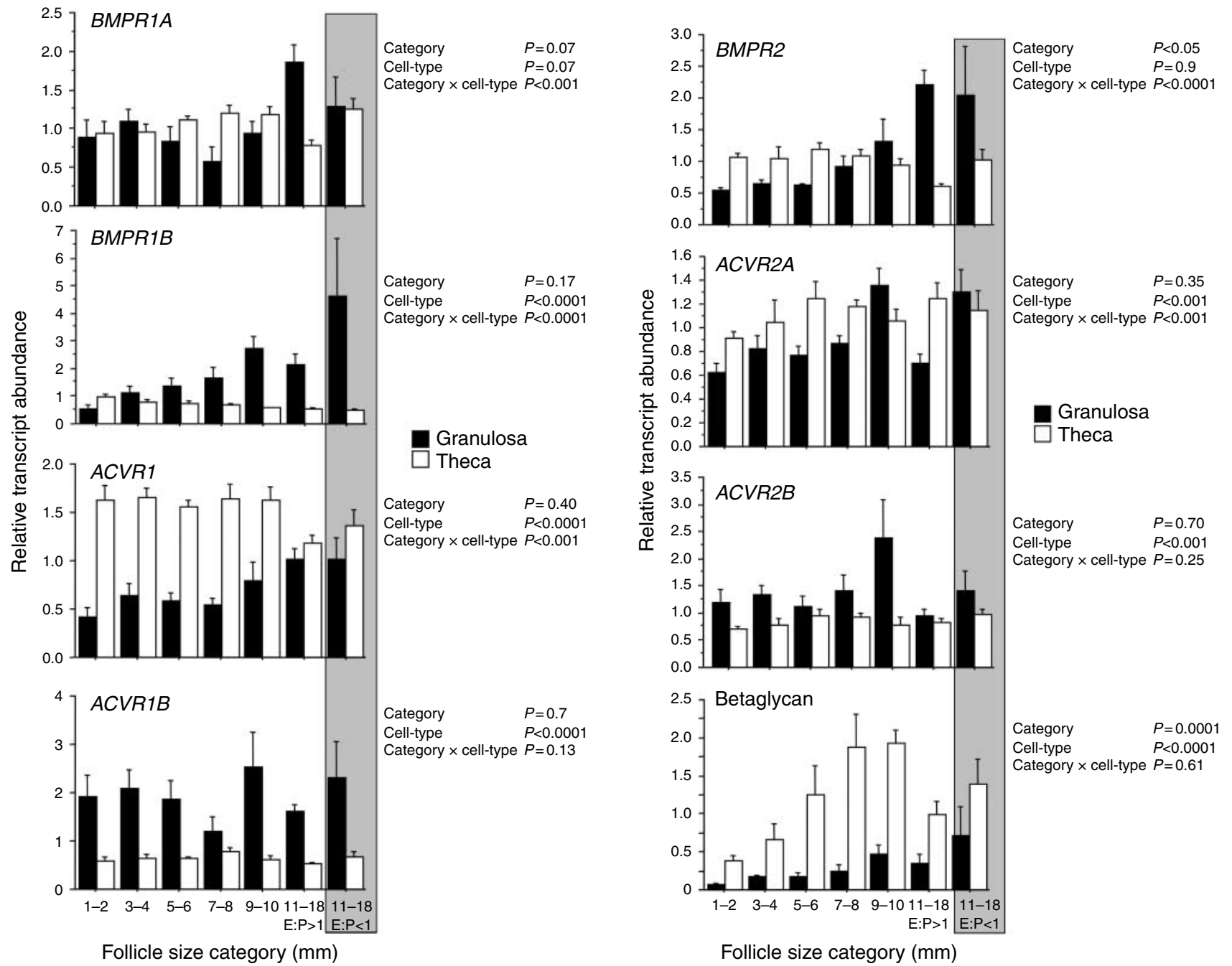

Figure 4 Changes in relative abundance of mRNA transcripts for BMP-responsive type I (BMPR1A, BMPR1B, $A C V R 1$ and $A C V R 1 B)$ and type II (BMPR2, ACVR2A and $A C V R 2 B$ ) signalling receptors and betaglycan in thecal and granulosal compartments of developing bovine antral follicles. Follicles in the $11-18 \mathrm{~mm}$ size class have been subdivided on the basis of oestrogen to progesterone ratio ( $\mathrm{E}: \mathrm{P}$ ratio) as 'oestrogen-

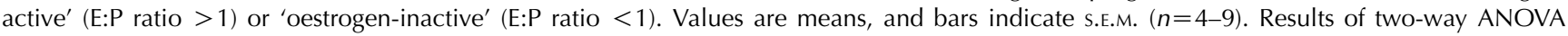
are summarized.

Follicle diameter was positively correlated with $\mathrm{E}_{2}: \mathrm{P}_{4}$ ratio and with GC abundance of mRNAs for CYP19, LHCGR, BMP4, INHA, INHBA, INHBB, betaglycan (TGFBR3) and five of seven BMP/activin receptors. Of the BMP ligand transcripts examined, $B M P 2$ expression was positively associated with BMP4 and $B M P 6$ expression but negatively associated with expression of several established markers of healthy dominant follicles (CYP19, FSHR, INHA, INHBA and INHBB) and with $B M P R 1 A, A C V R 1 B, B M P R 2, A C V R 2 B$ and betaglycan expression. There were many positive associations between expression levels of the seven BMP/activin receptors and betaglycan. Notably, there was a very high correlation between $B M P R 1 B$ and betaglycan mRNA abundance in GC $(r=0.91 ; P<0.0001)$.

\section{Correlations among expression levels of different transcripts in TC of developing follicles}

Figure 7 shows the corresponding pairwise relationships between follicle diameter, $\mathrm{E}_{2}: \mathrm{P}_{4}$ ratio and relative transcript abundance of 17 different transcripts in TC. There were far fewer significant correlations than in the corresponding GC samples. Nonetheless, follicle diameter was positively correlated with BMP2 transcript abundance and negatively correlated with $L H C G R$, $B M P R 1 B, A C V R 1, A C V R 1 B$ and BMPR2 transcript abundance. Follicular $\mathrm{E}_{2}: \mathrm{P}_{4}$ ratio was negatively correlated with BMPR1A, ACVR1, ACVR1B and BMPR2 transcript abundance in TC. LHCGR mRNA was positively associated with $C Y P 17, B M P 6, A C V R 1$ and $B M P R 2$ mRNA. Among the BMP ligands examined, 

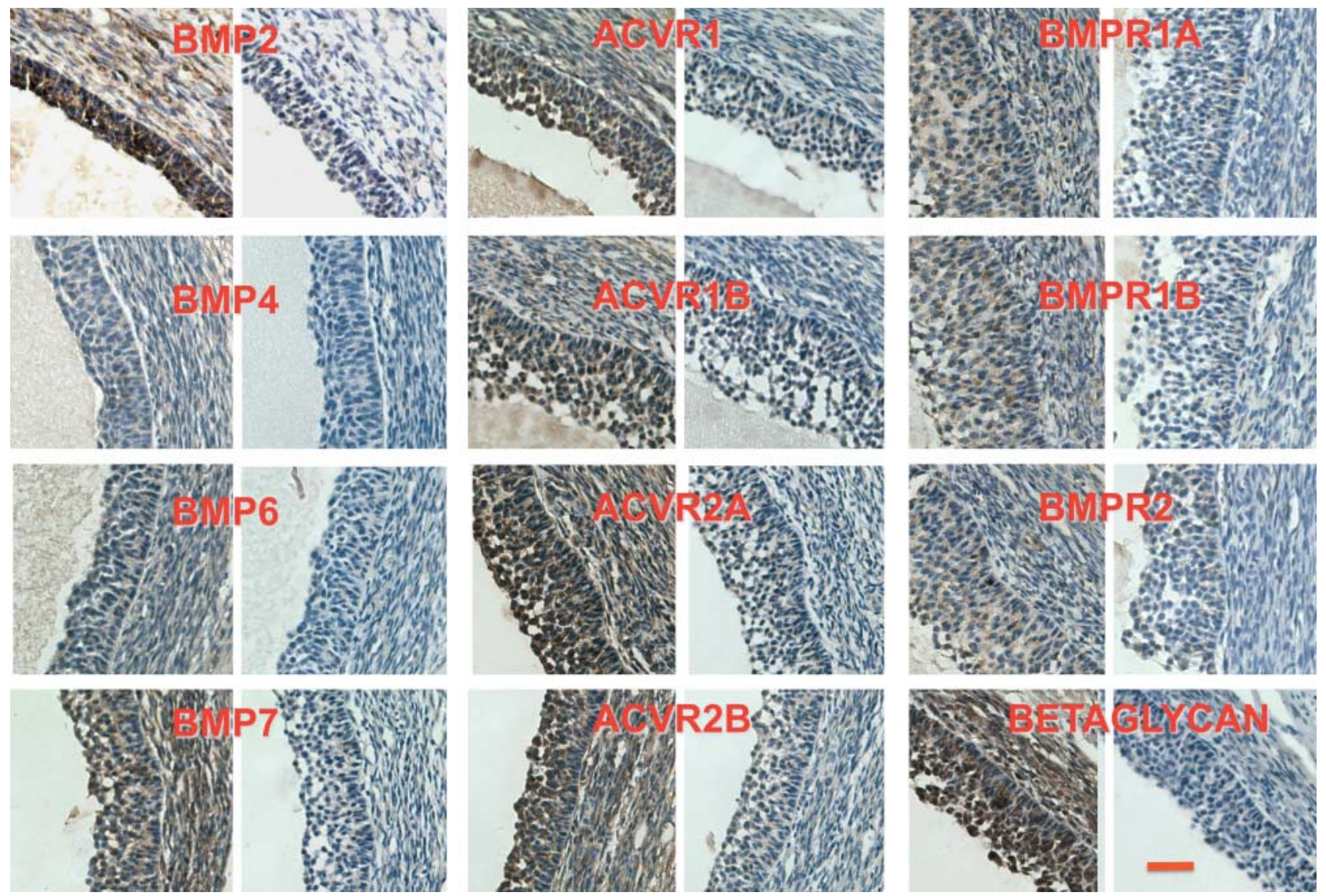

Figure 5 Immunohistochemical staining of bovine ovary sections showing the distribution of immunoreactive BMP ligands, BMP/activin receptors and betaglycan in the granulosa and theca layers of small antral follicles ( $\sim 3-5 \mathrm{~mm}$ diameter). In each panel, the left hand image shows an antibodytreated section, while the right hand image shows an adjacent section treated with the appropriate non-immune serum or purified IgG. All images were captured at the same magnification, and the scale bar in the lower right panel represents $50 \mu \mathrm{m}$.

there was a strong correlation between $B M P 2$ and $B M P 4$ mRNA abundance $(r=0.88 ; P<0.0001)$. Among the seven signalling receptors examined, 10/28 pairwise comparisons yielded significant positive correlations. For instance, $B M P R 1 A$ was positively correlated with $A C V R 1, A C V R 1 B$ and BMPR2, while BMPR1B was positively correlated with $A C V R 1 B$ and $B M P R 2$ transcript abundance. Although betaglycan expression was not correlated with follicle diameter when the whole set of follicle samples was considered (see Fig. 7), a significant positive correlation was evident when $11-18 \mathrm{~mm}$ follicles were excluded from the analysis $(r=0.50 ; P<0.001, n=33)$.

\section{Can inhibin reverse the suppressive effect of BMP on thecal androgen production?}

The selective expression of betaglycan (inhibin co-receptor) in TC combined with the progressive fivefold increase observed during follicle development from 1-2 to $9-10 \mathrm{~mm}$ prompted us to evaluate the possibility that inhibin functions as a physiological antagonist of BMP action on bovine $\mathrm{TC}$, in a manner comparable to that documented for activin signalling. As shown in Fig. 8, BMP4, BMP6 and BMP7 abolished LH-induced $\mathrm{A}_{4}$ secretion $(P<0.01)$ and suppressed $C Y P 17$ transcript abundance $>200$-fold $(P<0.001)$. Co-treatment with inhibin-A reversed the suppressive action of all three BMPs $(P<0.001)$. BMPs also reduced, but to a much lesser degree (two- to ten-fold; $P<0.01$ ), the levels of three other TC transcripts examined: STAR, CYP11A1 and $L H C G R$ (Fig. 9). In each case, the suppressive effect of BMP was reversed by inhibin $(P<0.01)$.

\section{Which signalling receptor subtype(s) mediate the suppressive effect of BMPs on thecal androgen production?}

In an attempt to identify at least some of the receptor subtype(s) which mediate the suppressive effect of BMP4, BMP6 and BMP7 on thecal androgen secretion, $\mathrm{LH}$-treated TC were exposed to each BMP in the presence and absence of one of three soluble 'decoy' receptors (ectodomains (ECD) of BMPR1A, BMPR1B or ACVR2B). As shown in Fig. 10, the BMPR1A 'decoy' receptor selectively blocked the suppressive effect of 


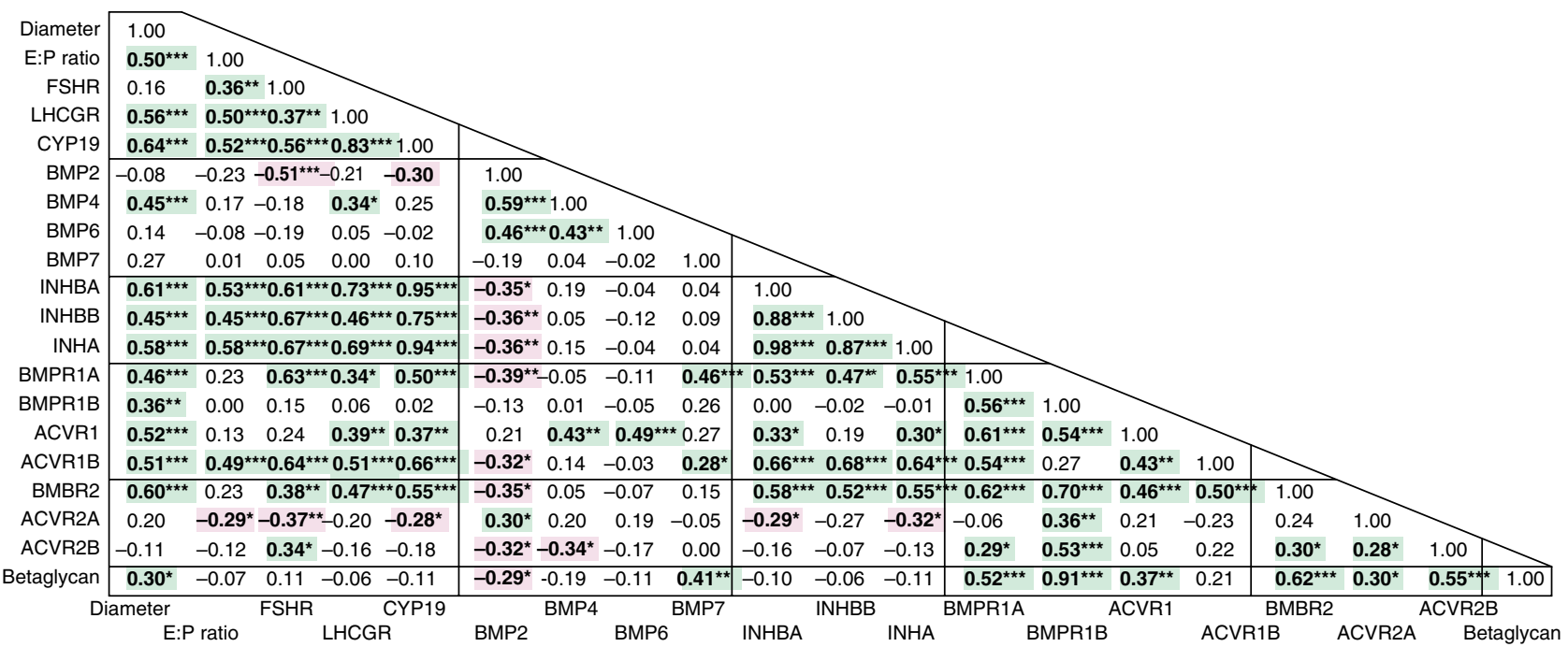

Figure 6 Correlation matrix showing the pairwise linear relationships between follicle diameter, follicular fluid $\mathrm{E}_{2}: \mathrm{P}_{4}$ ratio and relative abundance of the different GC transcripts quantified in ex vivo follicle samples $(n=47)$. Statistically significant $r$ values are in bold with green highlights indicating positive correlations and pink highlights indicating negative correlations. ${ }^{*} P<0.05,{ }^{* *} P<0.01,{ }^{* * *} P<0.001$.

BMP4 $(P<0.01)$ without reversing the effect of BMP6 or BMP7. The BMPR1B 'decoy' receptor blocked the suppressive effect of both BMP4 and BMP7 $(P<0.01)$ and partially reversed the effect of BMP6 $(P<0.1)$. In contrast, the ACVR2B 'decoy' receptor did not affect the response to any of the three BMPs tested, suggesting a low affinity for these ligands.

\section{Discussion}

The present study provides novel information on the spatio-temporal mRNA expression profiles for four BMPs (BMP2, BMP4, BMP6 and BMP7), associated type I (BMPR1A, BMPR1B, ACVR1 and ACVR1B) and type II
(BMPR2, ACVR2A and ACVR2B) signalling receptors and the inhibin co-receptor betaglycan during bovine antral follicle development. The relative abundance of mRNA transcripts for each of these targets was quantified in GC and TC layers isolated from follicles ranging in diameter from 1 to $18 \mathrm{~mm}$. This size range spans a number of key points in bovine follicle development including 'cyclic recruitment' of small antral follicles at 3-5 mm, dominant follicle 'selection' and 'deviation' at $\sim 6-8 \mathrm{~mm}, \mathrm{GC}$ acquisition of $\mathrm{LH}$ receptors at $\sim 9-10 \mathrm{~mm}$ and dominant oestrogen-active status at 11-18 mm (Ireland et al. 2000, Mihm et al. 2002, Ginther et al. 2003). As expected, follicles in the largest $(11-18 \mathrm{~mm})$ size category showed considerable

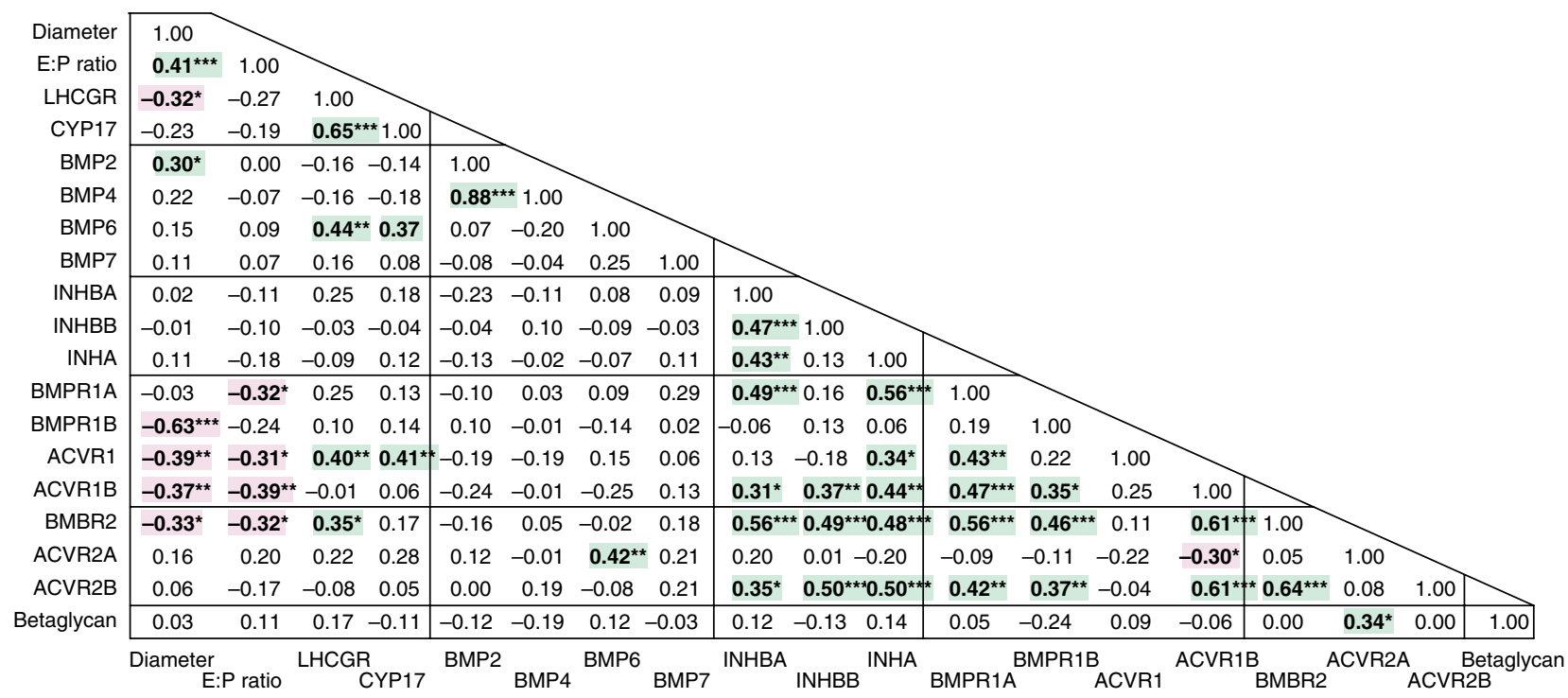

Figure 7 Correlation matrix showing the pairwise linear relationships between follicle diameter, follicular fluid $\mathrm{E}_{2}: \mathrm{P}_{4}$ ratio and relative abundance of the different TC transcripts quantified in ex vivo follicle samples $(n=47)$. Statistically significant $r$ values are in bold with green highlights indicating positive correlations and pink highlights indicating negative correlations. ${ }^{*} P<0.05,{ }^{* *} P<0.01,{ }^{* * *} P<0.001$. 

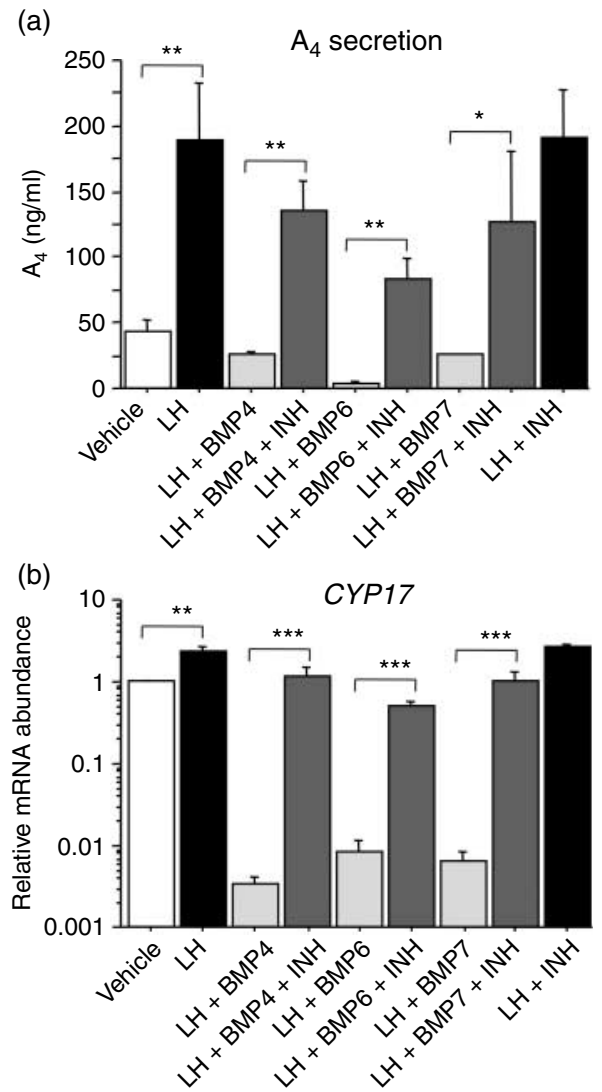

Figure 8 Effects of BMP4, BMP6 and BMP7, alone and in combination with inhibin, on (a) androstenedione secretion and (b) CYP17 mRNA expression by bovine TC (note use of log scale on $y$-axis). Values are means, and bars indicate S.E.M. ( $n=4$ independent cultures). ${ }^{*} P<0.05$ ${ }^{* *} P<0.01$ and ${ }^{* * *} P<0.001$ versus corresponding value.

variation in follicular fluid E:P ratio, reflecting their differing 'health' status. For this reason, we subdivided these follicles into LEA (presumptive 'healthy') and LEI (presumptive 'regressing') groups on the basis of their $\mathrm{E}: \mathrm{P}$ ratio, a widely used means of classifying bovine follicles (Ireland et al. 2000). No attempt was made to subdivide smaller follicles into presumptive 'healthy' or 'regressing' categories since E:P ratios in FF were well below 1 in all except two follicles (one in the $7-8 \mathrm{~mm}$ size class and one in the $9-10 \mathrm{~mm}$ size class). Furthermore, in the case of 1-2, 3-4 and 5-6 mm follicles, this was precluded by the pooling of individual follicles for analysis. It should also be noted that since the follicles analysed in this study were from cattle in the mid to late luteal phase of the oestrous cycle, most would belong to the first and/or second post-ovulatory wave of follicle development in which the likely fate of the selected oestrogen-active dominant follicle is regression rather than ovulation (Ireland et al. 2000, Mihm et al. 2002, 2006, Rodgers \& Irving-Rodgers 2010).

Analysis of key 'markers' of follicle status in the sample set included in the analysis (including follicular fluid $\mathrm{E}: \mathrm{P}$ ratio and expression of mRNA transcripts for gonadotrophin receptors, steroidogenic enzymes and INHBA subunit) revealed a pattern of expression consistent with previous work (Bao \& Garverick 1998, Webb et al. 2004), and confirmed that there was minimal cross-contamination of TC with GC, and vice versa. FSHR mRNA was abundant in GC throughout antral follicle development, consistent with the role of $\mathrm{FSH}$, acting exclusively on GC, in driving antral follicle development (Mihm et al. 2002, Webb et al. 2003). GC expression of $L H C G R$ was only detected in follicles $>9 \mathrm{~mm}$ in diameter, consistent with acquisition of $\mathrm{LH}$ dependency as they achieve dominance (Bao \& Garverick 1998, Webb et al. 2004), which is in agreement with the previous observations. Furthermore, expression levels of $L H C G R, C Y P 19$ and INHBA were all maximal in GC of LEA (presumptive 'healthy') follicles, being considerably lower in LEI (presumptive 'regressing') follicles. Together, the observed cell type and developmental stage-specific expression profiles of key gonadotrophin receptors, steroidogenic enzymes and INHBA subunit support the use of this follicle set to examine the expression pattern of BMP-related transcripts.

BMPs and other TGFB family members have emerged as potentially important regulators of follicle development (Shimasaki et al. 2004, Knight \& Glister 2006). We showed previously that BMP4, BMP6 and BMP7 can act upon both TC and GC in vitro, suppressing $\mathrm{LH}$-induced androgen production by TC (Glister et al. 2005) and enhancing $E_{2}$, inhibin-A, activin-A and follistatin secretion by GC (Glister et al. 2004). Furthermore, BMP treatment promoted rapid accumulation of phosphorylated SMAD1 in the nuclei of both GC and TC (Glister et al. 2004, 2005) confirming the activation of a functional BMP signalling pathway in these cells.

While previous immunocytochemical evidence for the bovine suggested that BMP4 and BMP7 are confined to TC and BMP6 to GC (Glister et al. 2004), in the present and previous (Kayani et al. 2009) studies, mRNA expression and immunoreactive protein were detected for all three BMPs in both TC and GC layers. BMP4 and $B M P 7$ transcripts were more abundant in TC than in GC in agreement with our earlier immunocytochemical evidence (Glister et al. 2004). However, at the mRNA level, BMP6 expression was much greater in TC than in GC. The explanation for this discrepancy is not known but may reflect a lack of specificity of the antibodies used in the previous study or, possibly, sequestration of BMP6 by TC-derived BMP-binding proteins rendering their epitopes undetectable by the BMP6 antibody used for immunocytochemistry. In any event, mRNA expression levels for BMP6 in each cell type were remarkably uniform across the different follicle stages analysed, perhaps indicating minimal involvement in follicle progression in this species.

Here, we also examined BMP2 expression and showed that mRNA abundance and BMP2 immunoreactivity were much higher in GC than in $\mathrm{TC}$ in 


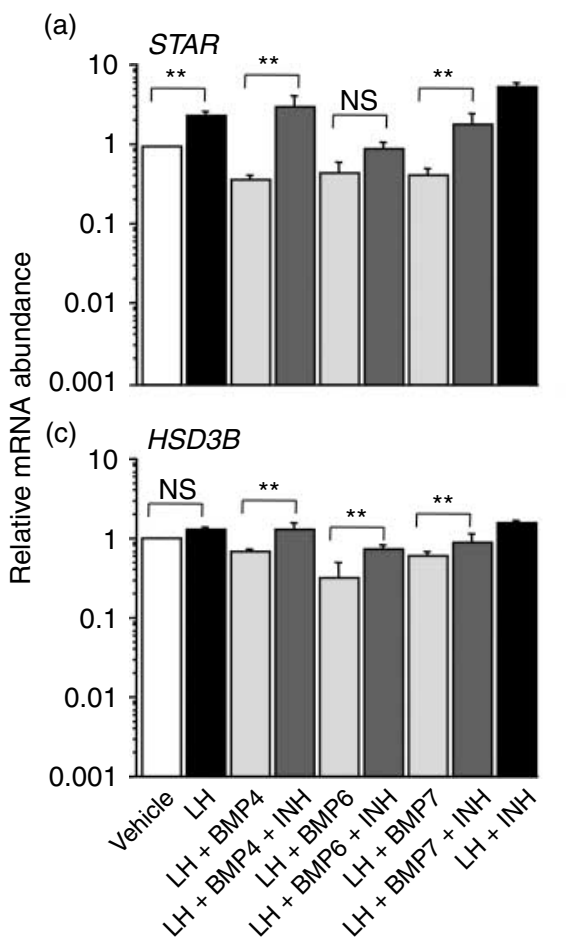

(b)
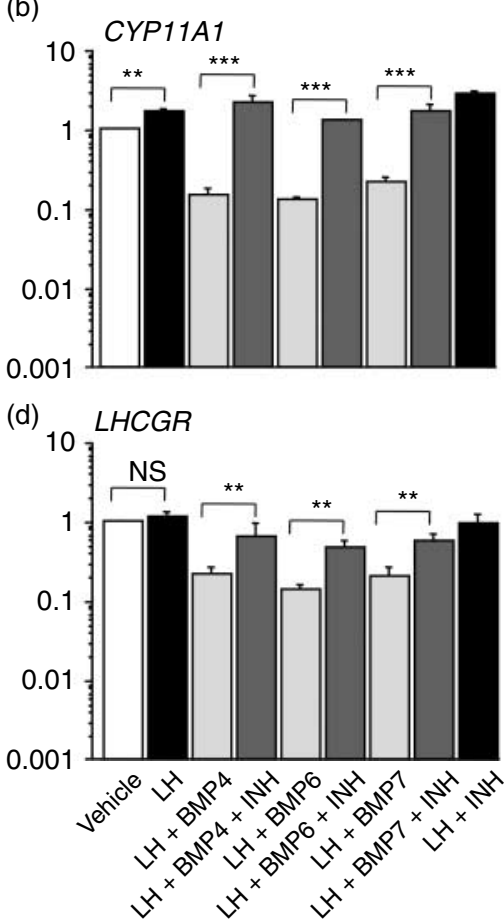

Figure 9 Effects of BMP4, BMP6 and BMP7, alone and in combination with inhibin, on the relative abundance of mRNA transcripts for (a) STAR, (b) CYP11A1, (c) HSD3B and (d) LHCGR (note use of log scale on $y$-axis). Values are means, and bars indicate S.E.M. ( $n=4$ independent cultures). ${ }^{* *} P<0.01$ and ${ }^{* * *} P<0.001$ versus corresponding value. agreement with our recent study (Kayani et al. 2009), but contradicting an earlier report (Fatehi et al. 2005) indicating BMP2 expression in TC but not in GC of bovine antral follicles. The reason for this inconsistency is not known but Juengel et al. (2006) also detected BMP2 mRNA by PCR in ovine GC. Moreover, using in situ hybridization, they were able to detect BMP2 mRNA in GC of large regressing follicles but not in GC of large healthy follicles. Interestingly, we found that BMP2 expression in GC fell about tenfold between the 7-8 $\mathrm{mm}$ and LEA stage, but was high again in LEI follicles that are presumed to be regressing, as evidenced by their loss of $\mathrm{E}_{2^{-}}$and inhibin-synthesizing capacity. In TC, BMP2 transcript abundance followed an inverse pattern to that seen in GC, although overall expression levels were much lower. Thus, low GC expression of BMP2 (but not BMP4, BMP6 or BMP7) appears to be an additional 'marker' of a healthy dominant follicle. This is further supported by the negative correlation between BMP2 and other key GC transcripts up-regulated in LEA follicles including CYP19, INHA, INHBA and INHBB. Within the context of intrafollicular paracrine signalling between GC and TC, we speculate that diminished production of $\mathrm{BMP} 2$ by $\mathrm{GC}$ of large $\mathrm{E}_{2}$-active follicles might facilitate thecal androgen production.

With regard to BMP/activin receptors, mRNA transcripts and positive immunoreactivity for each of the seven receptors were detected in both GC and TC layers at all follicle stages. Previously, we examined expression of five of these receptors using immunocytochemistry and confirmed that all five were present in both cultured bovine TC and GC (Glister et al. 2004). Our data are also consistent with the findings of Fatehi et al. (2005) who detected mRNA transcripts for BMPR1A, BMPR1B, $A C V R 1, A C V R 1 B$ and BMPR2 in both GC and TC layers of bovine antral follicles but did not examine $A C V R 2 A$ or $A C V R 2 B$ expression. Similarly, Souza et al. (2002) detected immunoreactive BMPR1A, BMPR1B and BMPR2 in both GC and TC layers of sheep antral follicles. Overall, among the type I receptors examined by QPCR in the present study, $B M P R 1 B$ and $A C V R 1 B$ transcripts were more abundant in GC, while $A C V R 1$ was more abundant in TC. Among type II receptors, $A C V R 2 A$ was higher in GC, while $A C V R 2 B$ was higher in TC.

With respect to follicle developmental stage, observed changes in receptor transcript abundance were generally

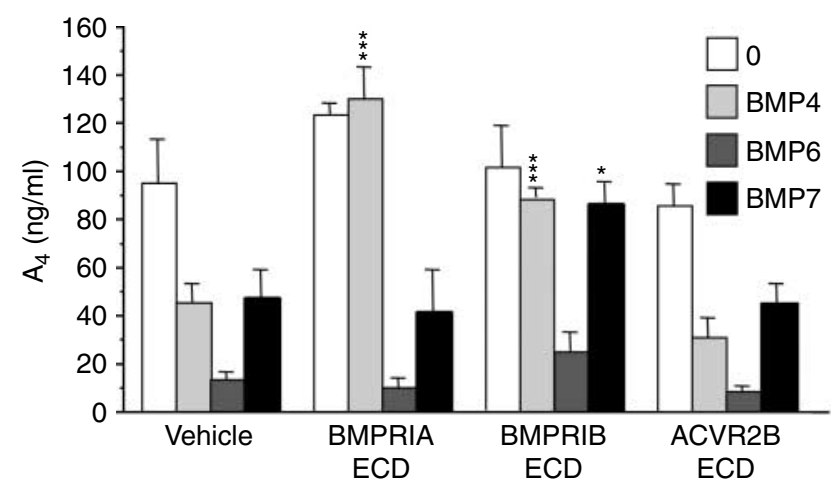

Figure 10 Effects of co-treatment with one of three soluble 'decoy' receptors (BMPR1A, BMPR1B and ACVR2B) on BMP-induced suppression of androstenedione secretion by bovine TC. Values are means, and bars indicate S.E.M. ( $n=4$ independent cultures). ${ }^{*} P<0.05{ }^{* *} P<0.01$ and ${ }^{* * *} P<0.001$ versus corresponding value. 
modest. However, two-way ANOVA indicated that TC and GC displayed quite different follicle stage-dependent expression patterns for five of the receptors $(B M P R 1 A$, $B M P R 1 B, A C V R 1, B M P R 2$ and ACVR2A). Indeed, the abundance of three of these transcripts in TC (BMPR1B, $A C V R 1$ and BMPR2) as well as $A C V R 1 B$ was negatively correlated with follicle diameter, while in GC, abundance of four of the above transcripts (BMPR1B, ACVR1, $A C V R 1 B$ and $B M P R 2)$ as well as BMPR $1 A$ was positively correlated with follicle diameter. In particular, both $B M P R 1 B$ and BMPR2 expression increased progressively in GC while decreasing slightly in TC. This suggests a progressive shift in the balance of GC/TC responsiveness to an intrafollicular BMP ligand(s) that signals via this particular combination of type I and type II receptors, with GC becoming more responsive as follicles increase in size while TC become less responsive. Ligands known to recruit this combination of type I and type II signalling receptors include BMP2, BMP4, BMP6, BMP7 and BMP15 (ten Dijke et al. 1994, Liu et al. 1995, Nohno et al. 1995, Yamashita et al. 1995, Ebisawa et al. 1999, Aoki et al. 2001, Moore et al. 2003).

As a step towards identifying which particular signalling receptors mediate the BMP-induced suppression of androgen production by bovine TC (Glister et al. 2005), we attempted to use a soluble 'decoy' receptor approach. Our finding that a soluble ECD of BMPR1A could selectively abolish the effect of BMP4, while soluble ECD of BMPR1B could block the effects of BMP4 and BMP7 (while partially reversing the effect of BMP6), supports the involvement of both of these type I receptors. Evidently, BMP4 binds strongly to both BMPR1A and BMPR1B, while BMP7 binds to BMPR1B but not to BMPR1A. A comprehensive analysis of the effects of different combinations of soluble ECD for all seven potential signalling receptors was beyond the scope of this study, but would be a potentially valuable approach for future work. A complementary in vitro strategy would be to use RNA interference to down-regulate the expression of selected combinations of type I and type II receptors before treating the cells with different BMPs.

In contrast to the relatively modest follicle stagedependent changes in BMP ligands and their type I and type II signalling receptors, we found that expression of betaglycan (TGFBR3) mRNA followed a distinct pattern during follicle development. Not only was betaglycan transcript abundance much greater in TC than in GC but its expression increased approximately fivefold in a stepwise fashion as follicles grew, reaching a peak in TC of $9-10 \mathrm{~mm}$ follicles before falling about $50 \%$ in the largest size class (11-18 mm), irrespective of oestrogenic status. We confirmed that betaglycan immunoreactivity was present in both the TC and GC layers of bovine antral follicles and in cultured bovine TC. Since betaglycan is considered an essential co-receptor required to facilitate the presentation of inhibin to type II signalling receptors and hence disrupt activin signalling (Lewis et al. 2000,
Chapman et al. 2002, Makanji et al. 2008), this observation prompted us to use our bovine TC culture model to evaluate the possibility that GC-derived inhibin functions as a physiological antagonist of BMP signalling in the ovary, in a manner comparable to its welldocumented role as an activin antagonist.

BMP4, BMP6 and BMP7 each promoted a marked reduction in $\mathrm{LH}$-induced androgen secretion by $\mathrm{TC}$, which is in agreement with previous work (Glister et al. 2005). Real-time PCR revealed that all three BMPs greatly reduced CYP17 expression with lesser reductions in other key TC transcripts (STAR, CYP11A1, LHCGR and $H S D 3 B)$. When co-treated with inhibin, a dramatic reversal of the BMP-induced reduction in androgen secretion and CYP17 expression was observed. Moreover, the BMP-induced reductions in expression of other TC transcripts (STAR, CYP11A1, LHCGR and HSD3B) were also reversed by inhibin. To our knowledge, this is the first study to show that inhibin can function as a BMP antagonist in an ovarian model. Our evidence concurs with other reports showing that inhibin can antagonize BMP effects on immortalized testicular, adrenocortical and gonadotroph cells lines (Wiater \& Vale 2003, Farnworth et al. 2006).

In addition to being secreted into the peripheral circulation to negatively regulate pituitary $\mathrm{FSH}$ secretion (De Jong 1988, Bleach et al. 2001, Mihm et al. 2002), GC-derived inhibin may act on TC in a paracrine fashion (Hillier et al. 1991, Wrathall \& Knight 1995). As shown previously, inhibin-A levels in bovine follicular fluid increase in parallel with follicle growth (Glister et al. 2006). Here, we show that betaglycan mRNA expression in TC increases progressively during follicle growth from 1 to $10 \mathrm{~mm}$. This suggests that the ability of GC-derived inhibin to interact with neighbouring TC depends on this up-regulation of betaglycan expression in growing follicles. Since BMPs reduce $\mathrm{LH}$-induced androgen production, the action of inhibin would facilitate TC androgen output, required for the subsequent conversion to $\mathrm{E}_{2}$ by $\mathrm{GC}$ as follicles progress towards functional dominance.

In summary, we have shown that $\mathrm{TC}$ and $\mathrm{GC}$ expression of $B M P 2, B M P 4, B M P 6$ and $B M P 7$ and their associated signalling receptors show relatively modest changes during antral follicle growth in cattle. However, the inhibin co-receptor betaglycan undergoes dynamic changes in mRNA expression levels in TC throughout follicle growth. Inhibin, presumably acting via betaglycan, can reverse the suppressive action of BMPs on androgen production and expression of key steroidogenic genes. Further experiments are required to explore these putative interactions of inhibin, betaglycan and BMPs in the ovarian follicle. In addition, information is required on the follicular expression patterns of extracellular BMP binding proteins and on the endocrine and/or local factors that modulate the expression of these potentially important regulators of BMP signalling. 


\section{Materials and Methods}

All media and reagents were purchased from Sigma UK Ltd (Pool, Dorset, UK) or Fisher Scientific Ltd (Loughborough, Leicestershire, UK) unless stated otherwise.

\section{Ovaries and isolation of granulosa and theca cells for ex vivo analysis of gene expression}

Ovaries from non-pregnant cattle slaughtered at random stages of the oestrous cycle were collected from an abattoir and transported to the laboratory on ice in medium-199 supplemented with $1 \%(\mathrm{v} / \mathrm{v})$ antibiotic-antimycotic solution. The stage of the oestrous cycle (I-IV) was estimated by the morphological appearance of the corpus luteum (Ireland et al. 1980), and only ovaries judged to be from cattle in the mid to late luteal phase of the cycle (stage II-III; days 5-17) were selected for follicle dissection. Follicles ranging in diameter from 1 to $18 \mathrm{~mm}$ were dissected out from ovaries and sorted according to size. Any follicles showing obvious signs of degeneration were discarded at this stage. Individual follicles in the $1-2 \mathrm{~mm}$ (ten follicles per pool, $n=6$ pools collected), 3-4 mm (six follicles per pool; $n=7$ pools collected) and 5-6 mm (six follicles per pool; $n=6$ pools collected) categories were combined for further analysis, while all follicles $>7 \mathrm{~mm}$ in diameter were processed and analysed individually. Smaller follicles, pooled as above, were hemisected into $1 \mathrm{ml}$ of DPBS, and the interior of the follicle was gently scraped to remove the GC layer. After removing any cumulus-oocyte complexes from the Petri dish, the resulting suspensions were transferred to microcentrifuge tubes and briefly centrifuged ( $2 \mathrm{~min}, 2300 \mathrm{~g}$ ) to pellet the cells. Supernatants (follicular fluid and DPBS) were removed and stored for subsequent analysis of steroids and total protein content. With larger follicles $(>7 \mathrm{~mm})$, a sample of follicular fluid was aspirated using a needle and syringe before hemisection and recovery of GC as above. The remaining follicle halves (devoid of most of their GC) were then shaken vigorously in DPBS, and the media were changed three times to remove any remaining GC. Theca interna cell (TC) layers were then peeled away from the follicle halves with the aid of a dissecting microscope as described previously (Glister et al. 2005). Peeled TC layers were briefly centrifuged to remove any dissecting medium. All GC and TC pellets were homogenized in $0.5 \mathrm{ml}$ of TRI Reagent before snap freezing and storage at $-80{ }^{\circ} \mathrm{C}$ for subsequent RNA purification and cDNA synthesis.

\section{Theca cell culture}

For in vitro experiments, TC layers pooled from $\sim 50$ follicles (4-6 mm diameter) per culture were collected as above and further processed as described by Glister et al. (2005) to obtain individual cell suspensions. The serum-free culture medium used throughout was McCoy's 5A modified medium supplemented with $1 \%(\mathrm{v} / \mathrm{v})$ antibiotic-antimycotic solution, $10 \mathrm{ng} / \mathrm{ml}$ insulin (bovine pancreas), $2 \mathrm{mM}$ L-glutamine, $10 \mathrm{mM}$ HEPES, $5 \mu \mathrm{g} / \mathrm{ml}$ apotransferrin, $5 \mathrm{ng} / \mathrm{ml}$ sodium selenite and $0.1 \%(\mathrm{w} / \mathrm{v})$ BSA. Cells were seeded at a density of 75000 viable cells $/ 50 \mu$ l culture medium into 96 -well tissue culture plates (Nunclon, Life Technologies Ltd, Paisley, UK) containing $200 \mu \mathrm{l} /$ well pre-equilibrated culture medium. Culture plates were incubated in a water-saturated atmosphere of $5 \% \mathrm{CO}_{2}$ and $95 \%$ air at $38.5{ }^{\circ} \mathrm{C}$ for a period of 6 days. Cell-conditioned medium was removed every $48 \mathrm{~h}$, and wells were replenished with fresh medium containing treatments (see below). Conditioned media were stored at $-20{ }^{\circ} \mathrm{C}$ for steroid immunoassays. At the end of the $144 \mathrm{~h}$ culture period, viable cell number was determined using neutral red uptake assay (Campbell et al. 1996, Glister et al. 2001).

\section{RNA isolation from cultured TC}

In culture experiments in which total RNA was to be extracted for PCR analysis, cells were seeded into 24-well plates $\left(0.5 \times 10^{6}\right.$ cells $\left./ \mathrm{ml}\right)$ with three replicate wells per treatment. At the end of culture, cell lysates were prepared using TRI Reagent, and pooled lysates from replicate wells were stored at $-80{ }^{\circ} \mathrm{C}$ until total RNA isolation.

\section{Preparation and addition of treatments}

Ovine LH (NIADDK oLH-S-16) was provided by the National Hormone and Pituitary Program (Torrance, CA, USA). Recombinant human (rh) BMP4, BMP6 and BMP7 and three soluble $B M P$ receptor $E C D-F C$ fusion protein constructs (BMPR1A, BMPR1B and ACVR2B) were purchased from R\&D Systems (Abingdon, Oxon, UK). Bovine 32 kDa inhibin-A was purified from bovine follicular fluid in this laboratory as described previously (Knight et al. 1990). Treatments were sterilized by passing through $0.2 \mu \mathrm{m}$ filters before further dilution in sterile culture medium. Each treatment was added at $25 \mu \mathrm{l}$ per culture well, and an equal volume of culture medium alone was added to the control wells.

\section{Hormone assays}

Concentrations of $\mathrm{A}_{4}$ in TC-conditioned media and follicular fluid samples were determined by RIA as reported previously (Wrathall \& Knight 1995, Glister et al. 2005). The detection limit was $100 \mathrm{pg} / \mathrm{ml}$, and intra- and inter-assay coefficients of variation $(\mathrm{CV})$ were 7 and $10 \%$ respectively. Concentrations of $\mathrm{P}_{4}$ in follicular fluid samples and TC-conditioned media were determined by competitive ELISA (Sauer et al. 1986, Bleach et al. 2001). The detection limit was $20 \mathrm{pg} / \mathrm{ml}$, and intra- and inter-assay $\mathrm{CV}$ values were 8 and $10 \%$ respectively. Concentrations of $E_{2}$ in follicular fluid samples were determined by RIA (Tannetta et al. 1998) with a detection limit of $2 \mathrm{pg} / \mathrm{ml}$ and intra- and inter-assay CV values of 6 and $9 \%$ respectively.

\section{Purification of RNA, CDNA synthesis and real-time PCR}

Total RNA was isolated from tissue samples and cultured TC using TRI Reagent (Sigma UK Ltd) according to the supplier's instructions. After aqueous phase separation, RNA was precipitated in isopropanol and washed in $75 \%(\mathrm{v} / \mathrm{v})$ ethanol, and the RNA pellet was re-suspended in $50 \mu$ l nuclease-free water. Potential genomic DNA contamination was removed 
Table 1 List of primers used for real-time PCR.

\begin{tabular}{|c|c|c|c|c|}
\hline Target & Accession number & Forward primer $5^{\prime}-3^{\prime}$ & Reverse primer $5^{\prime}-3^{\prime}$ & $\begin{array}{c}\text { Amplicon } \\
\text { size (bp) }\end{array}$ \\
\hline$B M P 2$ & XM_866011.1 & CCAAGAGGCATGTGCGGATTAGCA & ТССТTТСССАТСGTGGССАAAAGT & 101 \\
\hline BMP4 & NM_001045877.1 & TTTATGAGGTTATGAAGCCCCCGGC & AGTTTCCCACCGCGTCACATTGTG & 104 \\
\hline BMP6 & XM_600972.2 & GGCCCCGTTAACTCGACTGTGACAAA & TTGAGGACGCCGAACAAAACAGGA & 108 \\
\hline$B M P 7$ & XM_612246.2 & TGCAAGATAGCCACTTCCTCACCGA & GGGATCTTGGAGAGATCAAACCGGA & 130 \\
\hline INHBA & NM_174363.1 & GAAGAGACCCGATGTCACCCAGC & TGTCGTCСТСТАTCTCСACGTACCCG & 113 \\
\hline$I N H B B$ & NM_176852.1 & ATGGCCTGGCCTCCTCCCG & CTTCAGGTAGAGCCACAGGCTGGC & 101 \\
\hline INHA & NM_174094.3 & GAGCCCGAGGACCAAGATGTCTCC & ССТСАGССТСТССАGСАТСТGGC & 91 \\
\hline BMPR1A & NM_001076800 & TGGATTGCCCTTACTGGTTCAGCGA & CCАCGССАТTТАСССАТССАСА & 105 \\
\hline$B M P R 1 B$ & XM 612088.2 & AAAGTGGCGTGGCGTGGCGAAAAGGTAGCT & CCCGTCССTTTGATATCTGCAGCAA & 147 \\
\hline BMPR2 & XM_617592.2 & СССАСТСТTСGGСАСССТGG & ССССGCAGTTATTTCССССG & 87 \\
\hline ACVR1 & NM_176663.2 & CATGGCCСCCGAAAGTTCTTGATGA & GCСАССТСССАСАAGACAАGTCСAAA & 102 \\
\hline$A C V R 1 B$ & XM_586402.2 & ССТСТСТGСТGСТСТGTTGTGTGCG & СССGTCCAGGTTGAAAATGGAGACC & 103 \\
\hline ACVR2A & NM_174227.2 & GCCACAAACCСGССАТАТСТСАСА & TGCСАGССТСАААСТTТАAСGССАA & 114 \\
\hline$A C V R 2 B$ & NM_174495.2 & ACAAGCCATCTATTGCCCACAGGGA & CTCAAACCGAACAGCCAGGCCAAA & 104 \\
\hline TGFBR3 & XM_001253071.2 & TGCACТTTCСТАТСССАСАAGCСG & CCAGATCATTGAGGCATCCAGCG & 197 \\
\hline LHCGR & NM_174381.1 & ATTGCCTCAGTCGATGCCCAGACC & AAAAAGCCAGCCGCGCTGC & 92 \\
\hline FSHR & NM_174061.1 & GCCAGCCTCACCTACСССAGC & AATTGGATGAAGGTCAGAGGTTTGCC & 75 \\
\hline CYP17 & NM_174304 & GACAAAGGCACAGACGTTGTGGTCA & TGATCTGCAAGACGAGACTGGCATG & 301 \\
\hline CYP19 & NM 174305.1 & CGCCACTGAGTTGATTTTTGCTGAGA & TAAGGCTTTGCGCATGACCAGGTC & 301 \\
\hline$A C T B$ & BC102948.1 & ATCCACCATCGGCAATGAGCGGTT & CGGATGTCGACGTCACACACTTCATG & 128 \\
\hline
\end{tabular}

with an RNase-free DNase kit (RQ1; Promega UK Ltd). The TRI Reagent extraction process was repeated, and the final RNA pellet was re-suspended in $20 \mu$ l nuclease-free water; RNA quantity and quality were evaluated by spectrophotometry at $260 / 280 \mathrm{~nm}$. First strand cDNA was synthesized from $1 \mu \mathrm{g}$ of RNA template using the Reverse-iT RT kit (used according to the manufacturer's protocol; ABgene, Epsom, Surrey, UK) in a $20 \mu \mathrm{l}$ reaction primed with random hexamers. Primers were designed using Primer Express software (version 1.5; Perkin-Elmer Applied Biosystems, Warrington, Lancs, UK). Primer sequences and accession numbers are shown in Table 1. In primer validation experiments, dissociation curve analysis and agarose gel electrophoresis were used to verify that each selected primer pair generated a single amplicon of the predicted size. cDNA template dilution curves were used to demonstrate satisfactory PCR efficiency ( $>85 \%$ ) and linearity. PCR assays were carried out in a volume of $25 \mu \mathrm{l}$, comprising $10 \mu \mathrm{l}$ cDNA template (equivalent to $20 \mathrm{ng}$ reverse-transcribed RNA), $1 \mu \mathrm{l}$ each forward and reverse primers (final concentration $0.4 \mu \mathrm{M}$ ) and $12 \mu \mathrm{l}$ QuantiTect SYBR Green QPCR $2 \times$ 'hot start' Master Mix (Qiagen). Samples were processed for 40 cycles on an ABI PRISM 7700 Sequence Detection System (Perkin-Elmer Applied Biosystems) with the following thermal cycling conditions: $15 \mathrm{~min}$ at $95^{\circ} \mathrm{C}$ (one cycle only) then $15 \mathrm{~s}$ at $95^{\circ} \mathrm{C}$ and $1 \mathrm{~min}$ at $60^{\circ} \mathrm{C}$ (40 cycles). The $\Delta \Delta C_{\mathrm{t}}$ method was used for semi-quantitative comparison of the abundance of each mRNA transcript. $C_{\mathrm{t}}$ values for each transcript in a given sample were first normalized to $\beta$-actin $C_{\mathrm{t}}$ value (which was uniform across all experimental groups: ANOVA $P>0.1)$. For cell culture experiments, the resultant $\Delta C_{\mathrm{t}}$ values for each treatment were then normalized to the $\Delta C_{t}$ value of the respective vehicle-treated control group. For ex vivo tissue samples, $\Delta C_{\mathrm{t}}$ values for each transcript in a given sample were normalized to the mean $\Delta C_{\mathrm{t}}$ value for that transcript in all tissue samples. For graphical presentation, $\Delta \Delta C_{\mathrm{t}}$ values were finally converted to fold differences using the formula: fold difference $=2^{\left(-\Delta \Delta C_{t}\right)}$.

\section{Immunohistochemistry}

Ovaries were fixed for $24 \mathrm{~h}$ in neutral-buffered formalin, dehydrated and embedded in paraffin wax. Pairs of adjacent sections $(6 \mu \mathrm{m})$ were mounted onto poly-L-lysine-coated slides (Polysene, Fisher), dewaxed and rehydrated. Endogenous peroxidase activity was quenched by incubation for $30 \mathrm{~min}$ in $0.3 \% \mathrm{v} / \mathrm{v}$ hydrogen peroxide in methanol. Microwave antigen retrieval was performed using citrate buffer $(10 \mathrm{mM}$, $\mathrm{pH}$ 6). After cooling, tissue sections were washed (PBS $+0.1 \%$ $(\mathrm{v} / \mathrm{v})$ Tween 20) and blocked for $1 \mathrm{~h}$ using 2.5\% (v/v) horse serum (ImmPRESS Kit, Vector Laboratories, Peterborough, UK). The following primary antibodies (and appropriately matched control serum/purified IgG for adjacent tissue section) were diluted in blocking buffer and incubated with sections overnight at $4{ }^{\circ} \mathrm{C}$ : rabbit anti-BMP2 (Peprotech EC Ltd, London, UK) at $5 \mu \mathrm{g} / \mathrm{ml}$; mouse anti-BMP4 (clone 66119; R\&D Systems) at $5 \mu \mathrm{g} / \mathrm{ml}$; mouse anti-BMP6 (clone 74219, R\&D Systems) at $5 \mu \mathrm{g} / \mathrm{ml}$; rabbit anti-BMP7 (Peprotech) at $20 \mu \mathrm{g} / \mathrm{ml}$; rabbit anti-betaglycan (Santa Cruz Biotechnology Inc., Santa Cruz, CA, USA) at 1/50; rabbit anti-BMPR1, BMPR1B and BMPR2 (gifts from Prof. C-H Heldin, Ludwig Institute, Uppsala, Sweden) each at 1/100; rabbit anti-ACVR1, ACVR1B, ACVR2A and ACVR2B (raised 'in-house' against synthetic peptides conjugated to PPD) each at $1 / 100$. Peptide sequences corresponded to residues 81-89, 55-63, 91-100 and 90-99 within the extracellular domains of the respective bovine activin receptors, and were synthesized and conjugated by Prof. N P Groome and Dr M Cranfield (Oxford Brookes University, UK). After incubation with primary antibody, slides were washed thoroughly in PBS/Tween, and the ImmPRESS Universal anti-mouse/rabbit IgG HRP polymerbased detection system (Vector Laboratories) was used with diaminobenzidine substrate according to the manufacturer's instructions. Sections were counterstained with haematoxylin, dehydrated and mounted under glass coverslips. Slides were viewed on a Zeiss Axioskop 2 microscope 
(20X objective; Carl Zeiss Ltd, Welwyn Garden City, Herts, UK), and images were acquired using a Zeiss Axiocam with Axiovision software.

\section{Statistical analysis}

Hormone data were log-transformed before statistical analysis to reduce heterogeneity of variance. QPCR data were analysed as $\Delta C_{t}$ values before conversion to relative fold difference values. Results were evaluated using one- and two-way ANOVA and, where indicated or referred to in the text, post hoc pairwise comparisons were made using Fisher's protected least significant difference (PLSD) test. In vitro results are presented as means \pm S.E.M. $(n=4)$ based on combined data from four independent culture experiments, each using follicle cells harvested from a different set of ovaries.

\section{Declaration of interest}

The authors declare that there is no conflict of interest that could be perceived as prejudicing the impartiality of the research reported.

\section{Funding}

This work was supported by the Biotechnology and Biological Sciences Research Council (grants BBS/B/10439 and BB/G017174/1 to P G Knight).

\section{Acknowledgements}

We thank Mr D Butlin and Mr S A Feist for assistance with immunohistology, Prof. C-H Heldin (Ludwig Institute for Cancer Research, Uppsala, Sweden) for the gift of antisera against BMP receptors and Prof. N P Groome and Dr M Cranfield (Oxford Brookes University, Oxford, UK) for providing the peptide-PPD conjugates used to raise antisera against activin receptors.

\section{References}

Aoki H, Fujii M, Imamura T, Yagi K, Takehara K, Kato M \& Miyazono K 2001 Synergistic effects of different bone morphogenetic protein type I receptors on alkaline phosphatase induction. Journal of Cell Science $\mathbf{1 1 4}$ 1483-1489.

Bao B \& Garverick HA 1998 Expression of steroidogenic enzyme and gonadotropin receptor genes in bovine follicles during ovarian follicular waves: a review. Journal of Animal Science 76 1903-1921.

Bleach EC, Glencross RG, Feist SA, Groome NP \& Knight PG 2001 Plasma inhibin $\mathrm{A}$ in heifers: relationship with follicle dynamics, gonadotropins, and steroids during the estrous cycle and after treatment with bovine follicular fluid. Biology of Reproduction 64 743-752. (doi:10.1095/ biolreprod64.3.743)

Campbell BK, Scaramuzzi RJ \& Webb R 1996 Induction and maintenance of oestradiol and immunoreactive inhibin production with FSH by ovine granulosa cells cultured in serum-free media. Journal of Reproduction and Fertility 106 7-16. (doi:10.1530/jrf.0.1060007)

Chapman SC, Bernard DJ, Jelen J \& Woodruff TK 2002 Properties of inhibin binding to betaglycan, InhBP/p120 and the activin type II receptors. Molecular and Cellular Endocrinology 196 79-93. (doi:10.1016/S03037207(02)00227-7)
Cook RW, Thompson TB, Jardetzky TS \& Woodruff TK 2004 Molecular biology of inhibin action. Seminars in Reproductive Medicine 22 269-276. (doi:10.1055/s-2004-831902)

ten Dijke P, Yamashita H, Sampath TK, Reddi AH, Estevez M, Riddle DL, Ichijo H, Heldin CH \& Miyazono K 1994 Identification of type I receptors for osteogenic protein-1 and bone morphogenetic protein-4. Journal of Biological Chemistry 269 16985-16988.

Dooley CA, Attia GR, Rainey WE, Moore DR \& Carr BR 2000 Bone morphogenetic protein inhibits ovarian androgen production. Journal of Clinical Endocrinology and Metabolism 85 3331-3337. (doi:10.1210/jc. 85.9.3331)

Ebisawa T, Tada K, Kitajima I, Tojo K, Sampath TK, Kawabata M, Miyazono K \& Imamura T 1999 Characterization of bone morphogenetic protein-6 signaling pathways in osteoblast differentiation. Journal of Cell Science 112 3519-3527.

Erickson GF \& Shimasaki S 2003 The spatiotemporal expression pattern of the bone morphogenetic protein family in rat ovary cell types during the estrous cycle. Reproductive Biology and Endocrinology 19. (doi:10.1186/1477-7827-1-9)

Farnworth PG, Stanton PG, Wang Y, Escalona R, Findlay JK \& Ooi GT 2006 Inhibins differentially antagonize activin and bone morphogenetic protein action in a mouse adrenocortical cell line. Endocrinology 147 3462-3471. (doi:10.1210/en.2006-0023)

Fatehi AN, van den Hurk R, Colenbrander B, Daemen AJ, van Tol HT, Monteiro RM, Roelen BA \& Bevers MM 2005 Expression of bone morphogenetic protein2 (BMP2), BMP4 and BMP receptors in the bovine ovary but absence of effects of BMP2 and BMP4 during IVM on bovine oocyte nuclear maturation and subsequent embryo development. Theriogenology 63 872-889. (doi:10.1016/j.theriogenology.2004. 05.013)

Findlay JK \& Drummond AE 1999 Regulation of the FSH receptor in the ovary. Trends in Endocrinology and Metabolism 10 183-188. (doi:10. 1016/S1043-2760(98)00144-1)

Ginther OJ, Beg MA, Donadeu FX \& Bergfelt DR 2003 Mechanism of follicle deviation in monovular farm species. Animal Reproduction Science 78 239-257. (doi:10.1016/S0378-4320(03)00093-9)

Glister C, Tannetta DS, Groome NP \& Knight PG 2001 Interactions between follicle-stimulating hormone and growth factors in modulating secretion of steroids and inhibin-related peptides by nonluteinized bovine granulosa cells. Biology of Reproduction 65 1020-1028. (doi:10. 1095/biolreprod65.4.1020)

Glister C, Kemp CF \& Knight PG 2004 Bone morphogenetic protein (BMP) ligands and receptors in bovine ovarian follicle cells: actions of BMP-4, -6 and -7 on granulosa cells and differential modulation of Smad-1 phosphorylation by follistatin. Reproduction 127 239-254. (doi:10. 1530/rep.1.00090)

Glister C, Richards SL \& Knight PG 2005 Bone morphogenetic proteins (BMP) $-4,-6$, and -7 potently suppress basal and luteinizing hormone-induced androgen production by bovine theca interna cells in primary culture: could ovarian hyperandrogenic dysfunction be caused by a defect in thecal BMP signaling? Endocrinology 146 1883-1892. (doi:10.1210/en.2004-1303)

Glister C, Groome NP \& Knight PG 2006 Bovine follicle development is associated with divergent changes in activin- $A$, inhibin- $A$ and follistatin and the relative abundance of different follistatin isoforms in follicular fluid. Journal of Endocrinology 188 215-225. (doi:10.1677/joe. 1.06485)

Harrison CA, Wiater E, Gray PC, Greenwald J, Choe S \& Vale W 2004 Modulation of activin and BMP signaling. Molecular and Cellular Endocrinology 225 19-24. (doi:10.1016/j.mce.2004.02.008)

Hasegawa Y, Miyamoto K, Abe Y, Nakamura T, Sugino H, Eto Y, Shibai H \& Igarashi $\mathbf{M} 1988$ Induction of follicle stimulating hormone receptor by erythroid differentiation factor on rat granulosa cell. Biochemical and Biophysical Research Communications 156 668-674. (doi:10.1016/ S0006-291X(88)80894-5)

Hillier SG, Yong EL, Illingworth PJ, Baird DT, Schwall RH \& Mason AJ 1991 Effect of recombinant activin on androgen synthesis in cultured human thecal cells. Journal of Clinical Endocrinology and Metabolism 72 1206-1211. (doi:10.1210/jcem-72-6-1206)

Hsueh AJ, Dahl KD, Vaughan J, Tucker E, Rivier J, Bardin CW \& Vale W 1987 Heterodimers and homodimers of inhibin subunits have different 
paracrine action in the modulation of luteinizing hormone-stimulated androgen biosynthesis. PNAS 84 5082-5086. (doi:10.1073/pnas.84.14. 5082)

Ireland JJ, Murphee RL \& Coulson PB 1980 Accuracy of predicting stages of bovine estrous cycle by gross appearance of the corpus luteum. Journal of Dairy Science 63 155-160. (doi:10.3168/jds.S0022-0302(80)82901-8)

Ireland J, Mihm M, Austin E, Diskin MG \& Roche JF 2000 Historical perspective of turnover of dominant follicles during the bovine estrous cycle: key concepts, studies, advancements, and terms. Journal of Dairy Science 83 1648-1658. (doi:10.3168/jds.S0022-0302(00)75033-8)

De Jong FH 1988 Inhibin. Physiological Reviews 68 555-607.

Juengel JL, Reader KL, Bibby AH, Lun S, Ross I, Haydon LJ \& McNatty KP 2006 The role of bone morphogenetic proteins 2, 4, 6 and 7 during ovarian follicular development in sheep: contrast to rat. Reproduction 131 501-513. (doi:10.1530/rep.1.00958)

Kayani AR, Glister C \& Knight PG 2009 Evidence for an inhibitory role of bone morphogenetic protein(s) in the follicular-luteal transition in cattle. Reproduction 137 67-78. (doi:10.1530/REP-08-0198)

Knight PG \& Glister C 2001 Potential local regulatory functions of inhibins, activins and follistatin in the ovary. Reproduction 121 503-512. (doi:10. 1530/rep.0.1210503)

Knight PG \& Glister C 2006 TGF-beta superfamily members and ovarian follicle development. Reproduction 132 191-206. (doi:10.1530/ rep.1.01074)

Knight PG, Castillo RJ, Glencross RG, Beard AJ \& Wrathall JH 1990 Isolation of bovine ovarian inhibin, its immunoneutralization in vitro and immunolocalization in bovine ovary. Domestic Animal Endocrinology 7 299-313. (doi:10.1016/0739-7240(90)90036-Y)

Lewis KA, Gray PC, Blount AL, MacConell LA, Wiater E, Bilezikjian LM \& Vale W 2000 Betaglycan binds inhibin and can mediate functional antagonism of activin signalling. Nature 404 411-414. (doi:10.1038/ 35006129)

Liu F, Ventura F, Doody J \& Massague J 1995 Human type II receptor for bone morphogenic proteins (BMPs): extension of the two-kinase receptor model to the BMPs. Molecular and Cellular Biology 15 3479-3486.

Makanji Y, Walton KL, Wilce MC, Chan KL, Robertson DM \& Harrison CA 2008 Suppression of inhibin A biological activity by alterations in the binding site for betaglycan. Journal of Biological Chemistry $\mathbf{2 8 3}$ 16743-16751. (doi:10.1074/jbc.M801045200)

Massague J \& Chen YG 2000 Controlling TGF-beta signaling. Genes and Development 14 627-644. (doi:10.1101/gad.14.6.627)

Mihm M, Crowe MA, Knight PG \& Austin EJ 2002 Follicle wave growth in cattle. Reproduction in Domestic Animals 37 191-200. (doi:10.1046/ j.1439-0531.2002.00371.x)

Mihm M, Baker PJ, Ireland JL, Smith GW, Coussens PM, Evans AC \& Ireland JJ 2006 Molecular evidence that growth of dominant follicles involves a reduction in follicle-stimulating hormone dependence and an increase in luteinizing hormone dependence in cattle. Biology of Reproduction 74 1051-1059. (doi:10.1095/biolreprod.105.045799)

Miyazawa K, Shinozaki M, Hara T, Furuya T \& Miyazono K 2002 Two major Smad pathways in TGF-beta superfamily signalling. Genes to Cells 7 1191-1204. (doi:10.1046/j.1365-2443.2002.00599.x)

Miyazono K, ten Dijke P \& Heldin CH 2000 TGF-beta signaling by Smad proteins. Advances in Immunology 75 115-157. (doi:10.1016/S00652776(00)75003-6)

Miyazono K, Maeda S \& Imamura T 2005 BMP receptor signaling: transcriptional targets, regulation of signals, and signaling cross-talk. Cytokine \& Growth Factor Reviews 16 251-263. (doi:10.1016/j.cytogfr.2005.01.009)

Miyazono K, Kamiya Y \& Morikawa M 2010 Bone morphogenetic protein receptors and signal transduction. Journal of Biochemistry 147 35-51. (doi:10.1093/jb/mvp148)

Moore RK, Otsuka F \& Shimasaki S 2003 Molecular basis of bone morphogenetic protein-15 signaling in granulosa cells. Journal of Biological Chemistry 278 304-310. (doi:10.1074/jbc.M207362200)
Nohno T, Ishikawa T, Saito T, Hosokawa K, Noji S, Wolsing DH \& Rosenbaum JS 1995 Identification of a human type II receptor for bone morphogenetic protein-4 that forms differential heteromeric complexes with bone morphogenetic protein type I receptors. Journal of Biological Chemistry 270 22522-22526. (doi:10.1074/jbc. 270.38.22522)

Rodgers RJ \& Irving-Rodgers HF 2010 Morphological classification of bovine ovarian follicles. Reproduction 139 309-318. (doi:10.1530/REP09-0177)

Sauer MJ, Foulkes JA, Worsfold A \& Morris BA 1986 Use of progesterone 11 -glucuronide-alkaline phosphatase conjugate in a sensitive microtitreplate enzymeimmunoassay of progesterone in milk and its application to pregnancy testing in dairy cattle. Journal of Reproduction and Fertility $\mathbf{7 6}$ 375-391. (doi:10.1530/jrf.0.0760375)

Shimasaki S, Moore RK, Otsuka F \& Erickson GF 2004 The bone morphogenetic protein system in mammalian reproduction. Endocrine Reviews 25 72-101. (doi:10.1210/er.2003-0007)

Souza CJ, Campbell BK, McNeilly AS \& Baird DT 2002 Effect of bone morphogenetic protein 2 (BMP2) on oestradiol and inhibin A production by sheep granulosa cells, and localization of BMP receptors in the ovary by immunohistochemistry. Reproduction 123 363-369. (doi:10.1530/ rep.0.1230363)

Tannetta DS, Feist SA, Bleach ECL, Groome NP, Evans LW \& Knight PG 1998 Effects of active immunization of sheep against an amino terminal peptide of the inhibin $\alpha C$ subunit on intrafollicular levels of activin A, inhibin A and follistatin. Journal of Endocrinology 157 157-168. (doi:10. 1677/joe.0.1570157)

Webb R, Nicholas B, Gong JG, Campbell BK, Gutierrez CG, Garverick HA \& Armstrong DG 2003 Mechanisms regulating follicular development and selection of the dominant follicle. Reproduction. Supplement $\mathbf{6 1}$ 71-90.

Webb R, Garnsworthy PC, Gong JG \& Armstrong DG 2004 Control of follicular growth: local interactions and nutritional influences. Journal of Animal Science 82 (E-Suppl) E63-E74.

Welt C, Sidis Y, Keutmann H \& Schneyer A 2002 Activins, inhibins, and follistatins: from endocrinology to signaling. A paradigm for the new millennium. Experimental Biology and Medicine 227 724-752.

Wiater E \& Vale W 2003 Inhibin is an antagonist of bone morphogenetic protein signaling. Journal of Biological Chemistry 278 7934-7941. (doi:10.1074/jbc.M209710200)

Wrathall JH \& Knight PG 1995 Effects of inhibin-related peptides and oestradiol on androstenedione and progesterone secretion by bovine theca cells in vitro. Journal of Endocrinology 145 491-500. (doi:10. 1677/joe.0.1450491)

Xiao S, Robertson DM \& Findlay JK 1992 Effects of activin and follicle-stimulating hormone (FSH)-suppressing protein/follistatin on FSH receptors and differentiation of cultured rat granulosa cells. Endocrinology 131 1009-1016. (doi:10.1210/en.131.3.1009)

Yamashita $H$, ten Dijke P, Huylebroeck D, Sampath TK, Andries M, Smith JC, Heldin CH \& Miyazono K 1995 Osteogenic protein-1 binds to activin type II receptors and induces certain activin-like effects. Journal of Cell Biology 130 217-226. (doi:10.1083/jcb.130.1.217)

Ying SY 1988 Inhibins, activins, and follistatins: gonadal proteins modulating the secretion of follicle-stimulating hormone. Endocrine Reviews 9 267-293. (doi:10.1210/edrv-9-2-267)

Received 11 May 2010

First decision 23 June 2010

Revised manuscript received 16 August 2010

Accepted 25 August 2010 